(啹.Soc.Cosmet.Chem.Jpn.'

$\left(\begin{array}{lll}\text { 報(2) } & 158-166 & (1997)\end{array}\right)$

\title{
金コロイドの化粧品への応用 ${ }^{1}$
}

荻野和男, 大田昌勝, 松井順一

鐘紡株式会社 化粧品研究所 $\dagger^{2}$

\begin{abstract}
塩化金酸をクエン酸ナトリウムで還元すると鮮やかなルビー色の金ヒドロゾルが得られた。この金ヒ ドロゾルにポリオキシエチレン硬化ヒマシ油（60 E.O.) (HC 60) やモノオレイン酸ポリオキシエチレン ソルビタン（20 E.O.) (PO 20) の上うな親水性非イオン性界面活性剂を加えると, 電解質の添加や涷結 に対する安定性が, 格段に向上した。これは, 負に帯電した微粒子同士の電気的反発と界面活性剤によ る立体的防御の二つの効果によるものと考光られる。HC 60 を含む金ヒドロゾルを配合したローション やクリームは, 太陽光暴露下で 3 年にわたって, 色調の変化がなく安定であった。

また，この金ヒドロゾルと絹フィブロイン水溶液を混合，強攪拌するとフィブロインが結晶化して赤 紫色のシルクパウダーが得られた。これを TEM 観察すると，金微粒子は，フィブロイン中に均一に分 散していることが確認された。このシルクパウダーの色は, 熱や光に変色せず, 水や油に滲み出ること がないなど安定性の高いものであった。
\end{abstract}

\section{1. 緒訔}

化粧品に利用されている色素は, 安全性の面か ら数が限られているとともに，光照射下で長期間 にわたって色調が変化しないものは極めて少ない。 特に赤系の色調は, 利用価値が高く, 安全で安定 な新しい着色剂の開発が望まれている。

一方, 金コロイド (金の超微粒子が均一に分散 された状態）が，「カシウスの紫」と呼ばれる鮮 やかな赤色～赤紫色に発色することは古くから知 られており，ガラスや陶磁器の着色に利用されて きた。これらの色が太陽光を浴びながら百年以上 を経た現在も, その鮮やかさを保っている事実は, 金コロイドの色が一般の有機色素と比較にならな いほど安定であることを物語っている。しかし， 金微粒子そのものは固体表面に固定しないと極め て不安定で凝集しやすいために, 金コロイドを溶 液の着色剤として利用することや, 粉末状の着色

$\dagger^{1}$ 1996. 10. 2 受理

$\dagger^{2}$ ₹250 小田原市寿町5-3-28:3-28, 5-Chome,

Kotobuki-cho, Odawara-shi, Kanagawa 250, Japan
剤として取り扱うことはほとんどなされていない。 本報では，塩化金酸を還元して得た金ヒドロゾ ルの赤色を利用した安全性, 安定性に優れた化粧 品用着色剂の開発について報告する。

\section{2. 実 験 方 法}

\section{1 試料}

塩化金酸 $\left(\mathrm{HAuCl}_{4} \cdot 4 \mathrm{H}_{2} \mathrm{O}\right)$, クエン酸ナトリウ 厶, 水素化ホウ素ナトリウム (以上, 和光純薬), アスコルビン酸ナトリウム (東京化成工業), D-グ ルコース (国産化学)は, 試薬グレードを用いた。

本研究に用いた界面活性剤は, 以下の通りで化 粧品グレードである。

塩化ステアリルトリメチルアンモニウム $\mathrm{SC}$ (東京化成)

ラウリル硫酸ナトリウム SLS (日光ケミカル) ポリオキシエチレン硬化ヒマシ油（20 E.O.）

HC 20 (日光ケミカル)

ポリオキシエチレン硬化ヒマシ油（40 E.O.）

HC 40 (日光ケミカル)

ポリオキシエチレン硬化ヒマシ油（60 E.O.） 
HC 60 (日光ケミカル)

ポリオキシエチレン硬化ヒマシ油(100 E.O.)HC

100 (日光ケミカル)

モノラウリン酸ポリオキシエチレンソルビタン

（20 E.O.） PL 20(花王)

モノパルミチン酸ポリオキシエチレンソルビタ

ン（20 E.O.） PP 20（花王）

モノオレイン酸ポリオキシエチレンソルビタン

(20 E.O.) PO 20（花王）

モノオレイン酸ポリオキシエチレンソルビタン

（6 E.O.） PO 6（花王）

シルクパウダーとフィブロイン水溶液(フィブ ロイン濃度 5.6\%）は，カネボウシルクエレガン スから入手した。なお, フィブロイン水溶液は, 天然絹を精練後, 塩化カルシウム水溶液に溶解し, 透析により脱塩したものである。

その他試薬，化粧品原料は, 試薬グレードまた は化粧品グレードである。

\section{2 金ヒドロゾルの調製}

基本的な金ヒドロゾルの調製方法は以下の通り である。塩化金酸 $0.05 \mathrm{mmol}$ を $94 \mathrm{ml}$ の水に溶解 し加熱沸騰させ還流しながら，還元郕水溶液 0.2 $\mathrm{mmol} / 5 \mathrm{ml}$ を加え，10 分間挸拌した。得られた赤 色の金ヒドロゾルを室温に冷却した後, 界面活性 郕水溶液 $10 \mathrm{mg} / 1 \mathrm{ml}$ を添加した。こうして得られ る金ヒドロゾル中の金濃度は, $98.5 \mathrm{ppm}$ である。

還元剤として水素化ホウ素ナトリウムを用いた 場合には, 中尾ら"の方法に従い, 界面活性剤は 還元の前に添加し, 反応は室温で行った。

\section{3 金ヒドロゾルの物性測定}

(吸収スペクトル測定)

金ヒドロゾルの吸収スペクトルは, 分光光度計

(島津 UV-2200) で測定した。

(電子顕微鏡䚌察)

ごく微量の金ヒドロゾルを銅メッシュに乗せた ポリビニルフォルマール薄膜上で乾燥し, 透過型 電子顕微鏡（日立 H-500）で観察した。着色シルク パウダーは, エポキシ樹脂に包埋し, 超薄切片を 観察した。

\section{(ら一電位測定)}

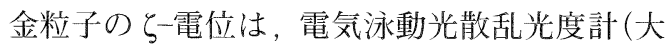

塚電子 ELS-800）によって測定した。

(安定性評価)

金ヒドロゾル $2.5 \mathrm{ml}$ に電解質水溶液 $2.5 \mathrm{ml}$ を 加え所定の濃度とし，24 時間後の色調変化，沈 殿生成を観察した。また，金ヒドロゾルを一 $22^{\circ} \mathrm{C}$ で 1 時間保存して凍結し, 再び融解して状態変化 を観察した。

\section{4 化粧品への応用}

（ローションの調製と耐光性評価）

Table-6に示す処方でローションを調製し，ガ ラス瓶中で太陽光に暴露し，色調の変化を分光光 度計にて吸收スペクトルを測定することにより評 価した。

(金ヒドロゾルのシルクパウダーへの染色性)

金ヒドロゾル $50 \mathrm{ml}$ 中にシルクパウダー $1 \mathrm{~g}$ を 懸濁し 1 時間攪找した後，濾過した。

(金コロイド着色シルクパウダーの調製)

$5.6 \%$ シルクフィブロイン水溶液 $357 \mathrm{~g}$ と金ヒ ドロゾル $1 \mathrm{~kg}$ を混合し，1時間，強攪找した。生 成したフィブロイン結晶を $\beta$-変成させるため 23 $\% \mathrm{NaCl}$ 水溶液 $200 \mathrm{~g}$ を加えた。1 時間攪找した後, 赤色のフィブロイン結晶を濾過，水洗，乾燥，粉 砕して金コロイド着色シルクパウダー $20 \mathrm{~g}$ を得 た。

(着色シルクパウダーの安定性評価)

着色シルクパウダーを金皿に圧縮成型して，太 陽米に 3 か月間暴露，あるいは， $105^{\circ} \mathrm{C}$ で 24 時

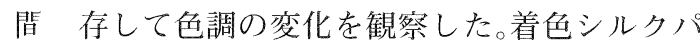
r'一を, 水, エタノール, スクアラン, ミリス 酸イソプロピル, ヒマシ油に分散, 懸濁して のブリードを観察した。

\section{3. 結果および考察}

\section{1 金ヒドロゾルの調製}

最も実用的な金ヒドロゾルの調製方法は，還元 剂を用いて塩化金酸水溶液を化学的に還元する方

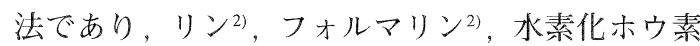
ナトリウム ${ }^{1)}$, メタノール ${ }^{3)}$, クエン酸4), クエン 酸ナトリウム4)等で赤い金ヒドロゾルが得られる ことが知られている。

皮膚に塗布する上での安全性を考慮すると，使 
用できる還元凨は限定される。本研究では, 化粧 品原料の中から還元性を持った物質として, クエ ン酸ナトリウム, アスコルビン酸ナトリウム, Dグルコースを選び，金ヒドロゾルの調製を検討し た。その結果, クエン酸ナトリウムを用いた場合 のみ，透明な赤い金ヒドロゾルを得た。アスコル ビン酸ナトリウムでは, ゾルにわずかに濁りを生 じ, D-グルコースでは，ゾルを得ることができ なかった。

以下の実験では，還元剛としてクエン酸ナトリ ウムを用いた。Fig.-1に塩化金酸水溶液をクエン 酸ナトリウムで還元して得た金ヒドロゾルの吸収 スペクトルを示す。

\section{2 金ヒドロゾルの安定化}

一般にコロイドは, 電解質の添加や凍結によっ

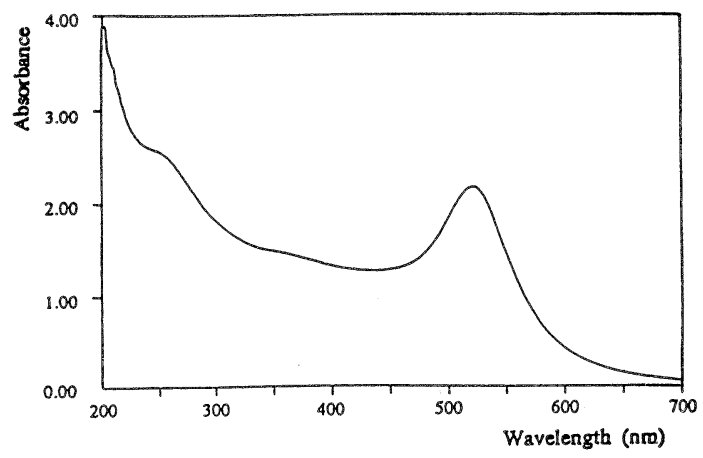

Fig.-1 Absorption spectrum of a gold hydrosol prepared from $\mathrm{HAuCl}_{4}$ and sodium citrate
て凝集し, 沈殿することが知られている。一方， 化粧品に打いては，処方中に電解質が添加される ことも多く，保存条件によっては凍結する場合も 想定される。そこで, クエン酸ナトリウムで還元 した金ヒドロゾルの，種々の電解質添加に対する 安定性を調べた結果をTable-1に示す。いずれ の電解質も $100 \mathrm{mM}$ 以上の添加では, 変色や沈殿 を招いた。金ヒドロゾルの安定性は, 㓌イオンの 価数に左右されないにもかかわらず，2 価陽イオ ンである $\mathrm{Mg}^{2+}$ は, 1 価の $\mathrm{Na}^{+} よ り$ 低濃度で沈殿 を生じさせた。Schulze-Hardy 則(5)から,この金ヒ ドロゾルは, 負の電荷を帯びていることが推定さ れる。また, この金ヒドロゾルを凍結すると青紫 色に変色し, やがてコロイドの凝集を生じ, 融解 すると沈殿した。

クエン酸ゾルは, 比較的安定な金ヒドロゾルと して知られるが, 電解質添加や凍結に対して, 化 粧品として実用化できるほどの安定性は有してい ないことが明らかとなった。

中尾らは, あらかじめ陽イオン性界面活性剤を 添加した塩化金酸溶液を水素化ホウ素ナトリウム で還元し安定性の高い金コロイドを得ているり。

著者らは, クエン酸ナトリウムで還元した金ヒ ドロゾルに，化粧品で使用される代表的界面活性 剂をゾル調製後に添加した時の安定化効果を検討 した。

初めに, 陽イオン性界面活性㓮として SC, 陰

Table-1 Effect of addition of electrolytes on the stability of gold hydrosol prepared from $\mathrm{HAuCl}_{4}$ and sodium citrate

\begin{tabular}{|c|c|c|c|c|c|c|}
\hline \multirow{2}{*}{ Electrolyte } & \multicolumn{5}{|c|}{ Electrolyte concentration (mM) } & \multirow[b]{2}{*}{300} \\
\hline & 1 & 3 & 10 & 30 & 100 & \\
\hline $\mathrm{NaCl}$ & $\mathrm{N}$ & $\mathrm{N}$ & $\mathrm{C}$ & $\mathrm{P}$ & $\mathrm{P}$ & $\mathrm{P}$ \\
\hline $\mathrm{Na}_{2} \mathrm{SO}_{4}$ & $\mathrm{~N}$ & $\mathrm{~N}$ & $\mathrm{~N}$ & $\mathrm{P}$ & $\mathrm{P}$ & $\mathrm{P}$ \\
\hline $\mathrm{MgCl}_{2}$ & $\mathrm{P}$ & $\mathrm{P}$ & $\mathrm{P}$ & $\mathrm{P}$ & $\mathrm{P}$ & $\mathrm{P}$ \\
\hline $\mathrm{MgSO}_{4}$ & $\mathrm{P}$ & $\mathrm{P}$ & $\mathrm{P}$ & $\mathrm{P}$ & $\mathrm{P}$ & $\mathrm{P}$ \\
\hline Citric acid-Sodium citrate $(\mathrm{pH} 4.0)$ & $\mathrm{N}$ & $\mathrm{N}$ & $\mathrm{C}$ & $\mathrm{P}$ & $\mathrm{P}$ & $\mathrm{P}$ \\
\hline $\mathrm{Na}_{2} \mathrm{HPO}_{4}-\mathrm{NaH}_{2} \mathrm{PO}_{4}(\mathrm{pH} 6.5)$ & $\mathrm{N}$ & $\mathrm{N}$ & $\mathrm{N}$ & $\mathrm{P}$ & $\mathrm{P}$ & $\mathrm{P}$ \\
\hline $\mathrm{Na}_{2} \mathrm{CO}_{3}-\mathrm{NaHCO}_{3}(\mathrm{pH} 9.0)$ & $\mathrm{N}$ & $\mathrm{N}$ & $\mathrm{N}$ & $\mathrm{N}$ & $\mathrm{P}$ & $\mathrm{P}$ \\
\hline
\end{tabular}

$\mathrm{N}:$ No change was observed.

$\mathrm{C}$ : The color of the hydrosol change to a dark violet shortly or in a day.

$\mathrm{P}$ : Black precipitates were deposited in a day. 
Table-2 Effect of addition of electrolytes on the stability of citrate-reduced gold hydrosol containing $\mathrm{HC} 60$

\begin{tabular}{lcccccc}
\hline \multirow{2}{*}{ Electrolyte } & \multicolumn{5}{c}{ Electrolyte concentration (mM) } \\
\cline { 2 - 7 } & 1 & 3 & 10 & 30 & 100 & 300 \\
\hline $\mathrm{NaCl}$ & $\mathrm{N}$ & $\mathrm{N}$ & $\mathrm{N}$ & $\mathrm{N}$ & $\mathrm{N}$ & $\mathrm{C}$ \\
$\mathrm{Na}_{2} \mathrm{SO}_{4}$ & $\mathrm{~N}$ & $\mathrm{~N}$ & $\mathrm{~N}$ & $\mathrm{~N}$ & $\mathrm{~N}$ & $\mathrm{~N}$ \\
$\mathrm{MgCl}_{2}$ & $\mathrm{~N}$ & $\mathrm{~N}$ & $\mathrm{~N}$ & $\mathrm{~N}$ & $\mathrm{~N}$ & $\mathrm{C}$ \\
$\mathrm{MgSO}_{4}$ & $\mathrm{~N}$ & $\mathrm{~N}$ & $\mathrm{~N}$ & $\mathrm{~N}$ & $\mathrm{~N}$ & $\mathrm{~N}$ \\
$\mathrm{Citric} \mathrm{acid-Sodium} \mathrm{citrate}(\mathrm{pH} 4.0)_{\mathrm{Na}_{2} \mathrm{HPO}_{4}-\mathrm{NaH}_{2} \mathrm{PO}_{4} \text { (pH 6.5) }}$ & $\mathrm{N}$ & $\mathrm{N}$ & $\mathrm{N}$ & $\mathrm{N}$ & $\mathrm{N}$ & $\mathrm{C}$ \\
$\mathrm{Na}_{2} \mathrm{CO}_{3}-\mathrm{NaHCO}_{3}$ (pH 9.0) & $\mathrm{N}$ & $\mathrm{N}$ & $\mathrm{N}$ & $\mathrm{N}$ & $\mathrm{N}$ & $\mathrm{N}$ \\
\hline
\end{tabular}

$\mathrm{N}:$ No change was observed.

$\mathrm{C}$ : The color of the hydrosol change to a dark violet shortly or in a day.

イオン性界面活性戍としてSLS，非イオン性界面 活性剤として HC 60 をそれぞれ $0.01 \%$ ずつ添加 して影響を調べた。HC 60 の添加は,ゾルに変化 を与えなかった。しかし，SCを添加すると，ゾ ルはすぐに暗紫色に変色し, やがてコロイドはす べて沈殿した。SLSの添加では, 赤色を保ったも のの，コロイドの一部が沈殿した。

HC 60 を添加した金ヒドロゾルの電解質添加に 対する安定性を調べた結果をTable-2に示す。 添加前と比較して安定性が格段に改善されている ことがわかる。また, 凍結, 融解しても, ゾルは 変化せず透明な赤い色調を保った。

そこで，非イオン性界面活性剂による安定化機 構を解明するため，エチレンオキサイド鎖の長さ を変えたポリオキシエチレン硬化ヒマシ油 $(\mathrm{HC})$ の添加効果を調べた。電解質は，ローションで一 般的に配合されることと $\mathrm{pH}$ の影響を排除するた
め,リン酸バッファーを用いた。その結果を Table3 に示す。20 モルから 60 モルへと, エチレンオ キサイド鎖が長くなる（HLB が増大する）に従 い，安定性が増すことがわかった。

次に, 活性剂の親油基の影響を検討するため, エチレンオキサイド鎖を有し化粧品で汎用されて いる活性剤としてポリオキシエチレンソルビタン 脂肪酸エステルを選び，その添加効果を調べた。 結果を Table-4に示す。ラウリル, パルミチル, オレイルの順にアルキル鎖長が長くなる（HLB が減少する）に従い，安定性が改善されることが わかった。PO 6 の場合, 親油基がオレイルであ るにもかかわらず安定化効果が現れないのは, 親 水基であるエチレンオキサイド鎖が短いためと考 えられる。

各種金ヒドロゾル中の金微粒子の 電位を Table-5に示す。

Table-3 Effect of polyoxyethylene hydrogenated castor oil on the stability of gold hydrosol prepared from $\mathrm{HAuCl}_{4}$ and sodium citrate

\begin{tabular}{ccccccc}
\hline & & \multicolumn{4}{c}{ Sodium phosphate buffer (mM) } & \multirow{2}{*}{ Freezing } \\
\cline { 3 - 5 } & HLB & 0 & 100 & 300 & 500 & \\
\hline HC 20 & 10.5 & $\mathrm{~N}$ & $\mathrm{C}$ & $\mathrm{C}$ & $\mathrm{C}$ & $\mathrm{N}$ \\
HC 40 & 12.5 & $\mathrm{~N}$ & $\mathrm{~N}$ & $\mathrm{C}$ & $\mathrm{C}$ & $\mathrm{C}$ \\
HC 60 & 14.0 & $\mathrm{~N}$ & $\mathrm{~N}$ & $\mathrm{~N}$ & $\mathrm{~N}$ & $\mathrm{~N}$ \\
HC 100 & 16.5 & $\mathrm{~N}$ & $\mathrm{~N}$ & $\mathrm{~N}$ & $\mathrm{~N}$ & $\mathrm{~N}$ \\
\hline
\end{tabular}

$\mathrm{N}$ : No change was observed.

$\mathrm{C}:$ The color of the hydrosol change to a dark violet shortly or in a day. 
Table-4 Effect of polyoxyethylene sorbitan fatty acid esters on the stability of gold hydrosol prepared from $\mathrm{HAuCl}_{4}$ and sodium citrate

\begin{tabular}{ccccccc}
\hline \multirow{2}{*}{ Surfactant } & HLB & \multicolumn{4}{c}{ Sodium phosphate buffer (mM) } & \multirow{2}{*}{ Freezing } \\
\cline { 3 - 5 } & & 0 & 100 & 300 & 500 & \\
\hline PL 20 & 16.7 & $\mathrm{~N}$ & $\mathrm{~N}$ & $\mathrm{~N}$ & $\mathrm{C}$ & $\mathrm{C}$ \\
PP 40 & 15.6 & $\mathrm{~N}$ & $\mathrm{~N}$ & $\mathrm{~N}$ & $\mathrm{C}$ & $\mathrm{N}$ \\
PO 60 & 15.0 & $\mathrm{~N}$ & $\mathrm{~N}$ & $\mathrm{~N}$ & $\mathrm{~N}$ & $\mathrm{~N}$ \\
PO 6 & 10.0 & $\mathrm{~N}$ & $\mathrm{C}$ & $\mathrm{P}$ & $\mathrm{P}$ & $\mathrm{C}$ \\
\hline
\end{tabular}

$\mathrm{N}$ : No change was observed.

$\mathrm{C}$ : The color of the hydrosol change to a dark violet shortly or in a day.

$\mathrm{P}$ : Black precipitates were deposited in a day.

Table-5 $\zeta$-Potential of gold hydrosol

\begin{tabular}{llc}
\hline \multicolumn{1}{c}{ Reductant } & Surfactant & $\zeta$-Potential $(\mathrm{mV})$ \\
\hline Sodium citrate & - & -20.4 \\
Sodium citrate & HC 60 & -19.2 \\
Sodium citrate & PO 20 & -28.4 \\
$\mathrm{NaBH}_{4}$ & SC & +22.3 \\
$\mathrm{NaBH}_{4}$ & SLS & -22.6 \\
$\mathrm{NaBH}_{4}$ & HC 60 & -0.3 \\
\hline
\end{tabular}

クエン酸ナトリウムで還元した金ヒドロゾルと 比較するため，SC，SLS，HC60をあらかじめ含 んだ塩化金酸溶液を水素化ホウ素ナトリウムで還 元し，金ヒドロゾルの調製を試みた。いずれの場 合も赤い金ヒドロゾルが得られたが，HC 60 で調 製したゾルは，不安定で数日のうちに沈殿した。 それぞれのら-電位をTable-5に示すが，水素化 ホウ素ナトリウムで還元した場合は，陽イオン性 界面活性剤である SC を用いると正，㓌イオン性 界面活性剤であるSLS を用いると負, 非イオン 性界面活性剤である HC 60 では，ほほ無電荷と いうように，コロイド粒子の電荷を界面活性剤が 決定していることがわかる。これは，本来，電荷 を持たない金微粒子の表面に界面活性剂が吸着し ていることによると考えられる。

一方，クエン酸ナトリウムで還元した金ヒドロ ゾルは，負の電荷を持っているが，これは，クエ ン酸分子の吸着によるものと言われている(6)。 れに，非イオン性界面活性剤を添加すると，HC 60 では，ほとんど電荷に影響を与えていないが, PO 20 では負電荷が増すことがわかった。
クエン酸ナトリウムで還元され，エチレンオキ サイド鎖を持つ非イオン性界面活性剤を含有する 金ヒドロゾルの驚くべき安定性は，以下の二つの 効果によるものと考えられる。第 1 に金微粒子は, 負の電荷を带びて打り，この電気的反発によって ある程度の安定性を保っている。電解質やイオン 性活性剂，特に正の電荷を持った金属イオンや陽 イオン性界面活性剤の添加は, この電気的バリア 一に影響して沈殿を引き起こすものと考えられる。 第 2 にコロイド粒子は，界面活性剤の立体的バリ アーで凝集から保護されている。界面活性郕は, 金微粒子に吸着して, そのエチレンオキサイド鎖 を水中に伸ばしていると推定される。

クエン酸ナトリウムで還元し，HC 60 を添加し た金ヒドロゾルの電子顕微鏡写真を Fig.-2に示 す。金微粒子の大きさは，約 $14 \mathrm{~nm}$ であった。

\section{3 化粧品への応用}

（金ヒドロゾルの安全性）

クエン酸ナトリウムで還元し，HC 60 を添加し た金ヒドロゾルの安全性試験結果をTable-6に 示す。皮膚一次刺激, 皮虞累積刺激, 眼粘膜刺激, 感作性, 変異原性, ヒトパッチ試験の結果は, す 心゙て陰性であった。

(金ヒドロゾルの化粧品への応用)

Table-7に示した処方でローションを調製し， 従来の有機色素と耐光性を比較した。約 3 年間, 太陽光を暴露した結果, 赤色 106 号, 赤色 227 号 を配合したローションが裉色したのと比較して， 金ヒドロゾルで着色したローションは, 全く色調 が変化しなかった。これらのローションのそれぞ 


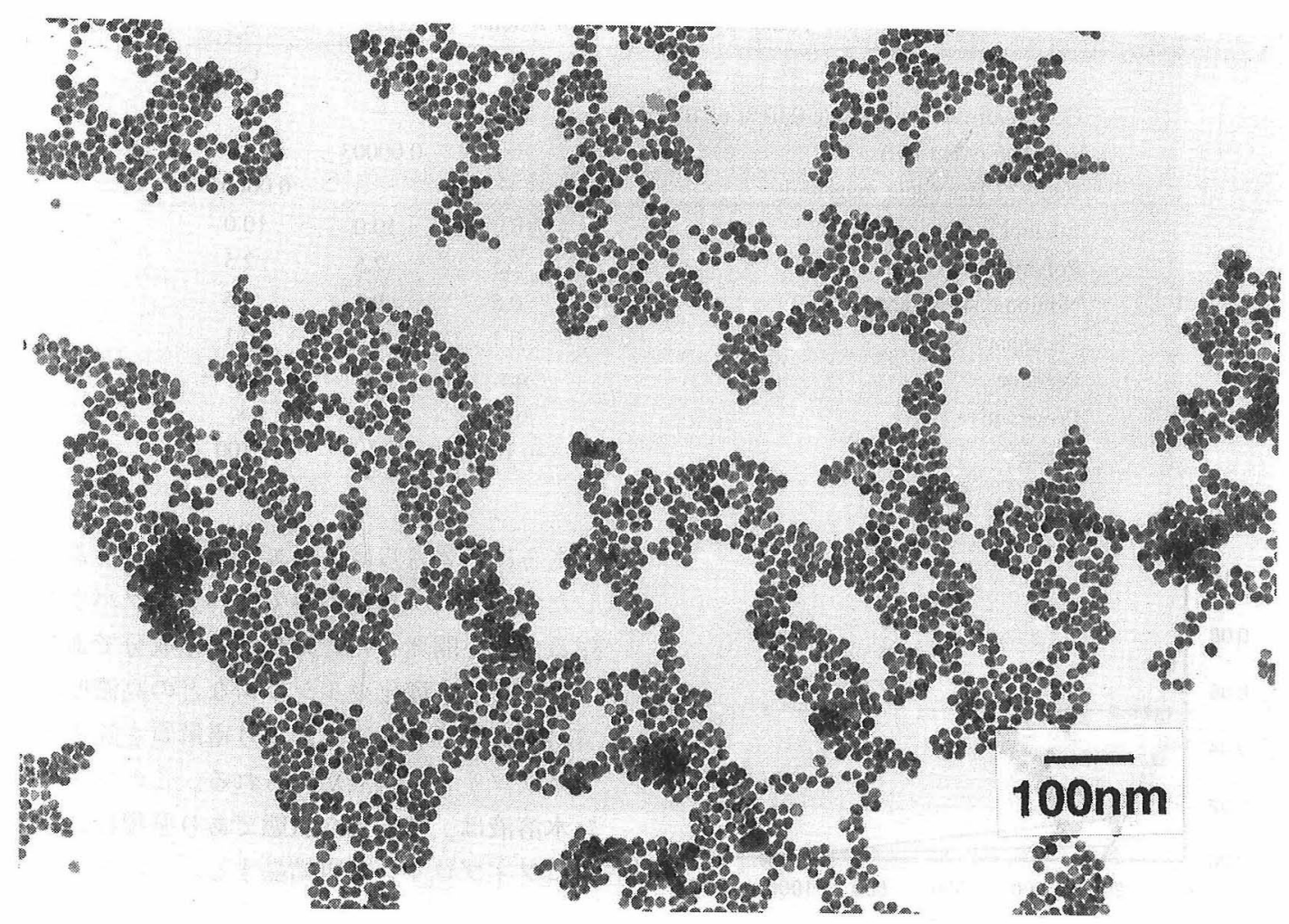

Fig.-2 Electron micrograph of colloidal gold in sodium citrate reduced hydrosol containing HC 60

Table-6 Safety of gold hydrosol prepared from $\mathrm{HAuCl}_{4}$ and sodium citrate

\begin{tabular}{l|l|l|l}
\hline \multicolumn{1}{c|}{ Test } & \multicolumn{1}{|c|}{ Animals } & \multicolumn{1}{c}{ Methods } & \multicolumn{1}{c}{ Results } \\
\hline Primary skin irritation & Rabbit & Draize & Non-irritant \\
Cumulative skin irritation & Rabbit & & Non-irritant \\
Eye irritation & Rabbit & Draize & Non-irritant \\
Sensitization & Guinea pig & Maximization & Negative \\
Mutagenicity & E. Coli, Salmonella & Ames & Negative \\
& typhimurium & & \\
Patch test & Human & Closed patch & Negative \\
\hline
\end{tabular}

れの極大吸収波長における吸光度の変化を Fig.3 に示す。

また，乳液，クリーム等の着色㓱として，金ヒ ドロゾルを配合し, 乳化することも可能であった。 これらの試作品も同様に, 太陽光暴露下で約 3 年 間, 全く色調が変化しなかった。

有機色素の発色機構が，その分子構造に由来し ているために変化しやすいのと比較して金コロイ ドの赤色は, プラズマ振動に基づく金原子そのも
のの吸収に由来している。従って金微粒子の凝集 を防いで, 安定な分散状態を保てばその色調は極 めて安定であり化粧品用の着色剛として有用であ ると考えられる。

（金コロイド着色シルクパウダーの調製と評 価)

メイクアップ化粧品に配合することを目的に金 コロイドの顔料化を試みた。中尾らは, カチオン 性界面活性郕である SC 存在下で水素化ホウ素ナ 
Table-7 Formulation of lotions

\begin{tabular}{lccc}
\hline & A & B & C \\
Gold hydrosol (containing 0.01\% of HC 60) & 3.0 & - & - \\
Red 106 (Acid red) & - & 0.00003 & - \\
Red 227 (Fast acid magenta) & - & & 0.00005 \\
Ethanol & 10.0 & 10.0 & 10.0 \\
Polyhydric alcohol & 2.5 & 2.5 & 2.5 \\
Nonionic surfactant & 0.5 & 0.5 & 0.5 \\
Phosphate buffer & 0.1 & 0.1 & 0.1 \\
Perfume & q.s. & q.s. & q.s. \\
Preservative & q.s. & q.s. & q.s. \\
Water & to 100 & to 100 & to 100 \\
\hline
\end{tabular}

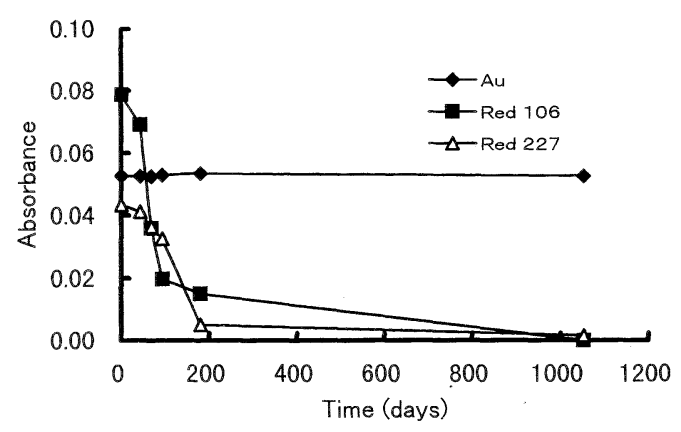

Fig. -3 Change of absorbance at maximum absorption wavelength of the lotions

トリウムで還元した金ヒドロゾルに浸漬すること で絹布を紫色に染色できたと報告している7)。著 者らは，Table-5に示した数種の金ヒドロゾル中 にシルクパウダーを懸濁し，染色することを試み た。その結果, クエン酸ナトリウムで還元した金 ヒドロゾルや水素化ホウ素ナトリウムで還元して も SLS，HC 60 を用いた金ヒドロゾルでは, シル クパウダーは染色されず, SC 存在下で水素化ホ ウ素ナトリウムで還元した金ヒドロゾル中に懸濁 した場合のみ赤紫色のシルクパウダーが得られた。 SC 存在下で水素化ホウ素ナトリウムで還元して 得た金微粒子は, SCの吸着により正に带電して いるため，負に帯電しているシルクパウダー表面 に吸着するものと考えられる。染色したシルクパ ウダーの割断面の TEM 写真を Fig. -4 に示す。 金微粒子は, シルクパウダーの表面にの及吸着し ていることがわかる。
さらに，著者らは，クエン酸ナトリウムで還元 した金ヒドロゾルを用いて赤いシルクパウダーを 作る方法を開発した。シルクの主成分であるフィ ブロインは, 塩化カルシウムなどの高濃度の電解 質溶液に溶解し, 透析により電解質を除去すると フィブロイン水溶液が得られる。このフィブロイ ン水溶液は, 準安定な状態であり強撌拌により容 易にフィブロインが再結晶する。この性質を利用 して，HC 60 を含むクエン酸ナトリウムで還元し た金ヒドロゾルとシルクフィブロイン水溶液とを 混合して強く攪拌するとフィブロインが結晶化す ると同時に赤紫色に着色し, 濾過, 粉砕すると赤 紫色のシルクパウダーが得られた。その割断面の 電子顕微鏡写真を Fig. - 5 に示す。金微粒子は, フ イブロイン内部へ均一に分散していることが観察 される。

この着色シルクパウダーの耐光性，耐熱性を前 述の方法で試験した結果，全く色調が変化せず安 定であった。また，化粧品基剤中へ色が滲及出す 事もなかった。このパウダーは, シルクパウダー 本来の保湿性, 肌に対する親和性, な女らかな感 触等を有しておりメイクアップ化粧品用の新たな 顔料として有用なものと考えられる。

\section{4. 結 論}

1）塩化金酸溶液を沸騰させながら，クエン酸 ナトリウム溶液を添加すると透明な赤い金ヒ ドロゾルが得られた。この金ヒドロゾルにポ リオキシエチレン硬化ヒマシ油(60 E.O.)や 


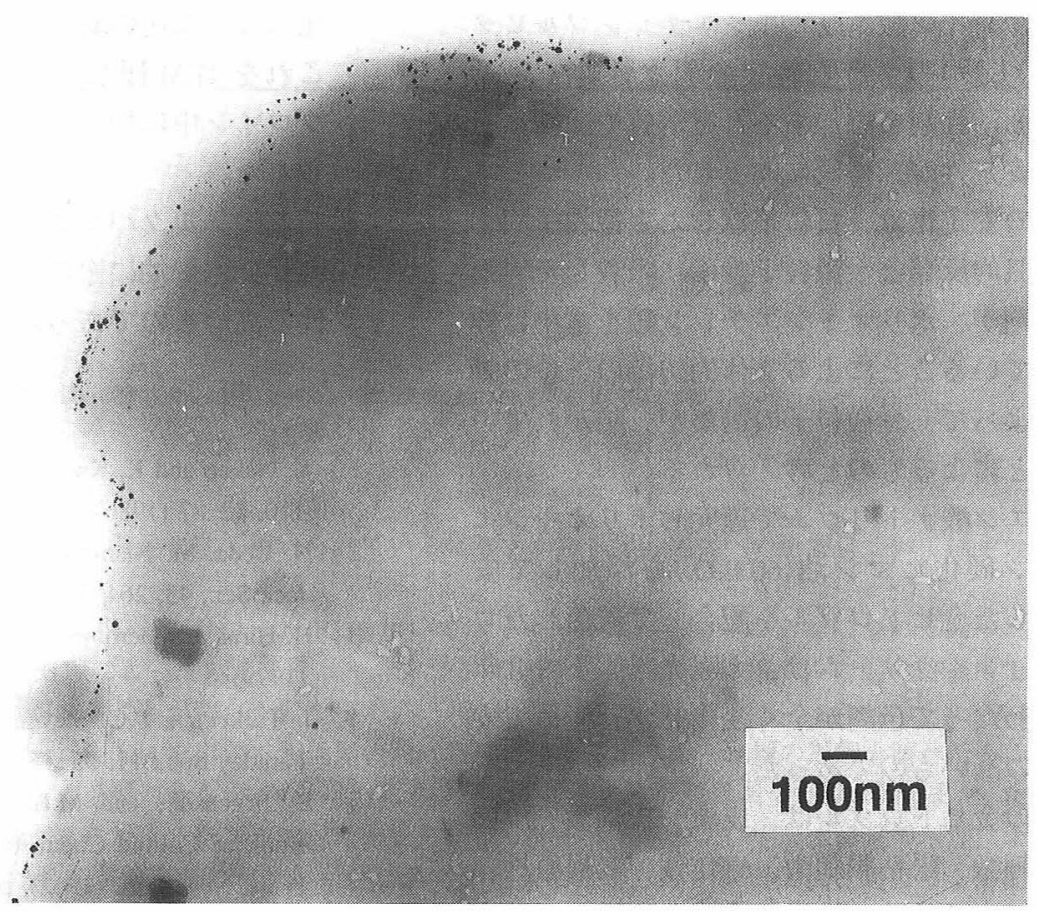

Fig. -4 Electron micrograph of a cross section of the silk powder dyed with gold particles

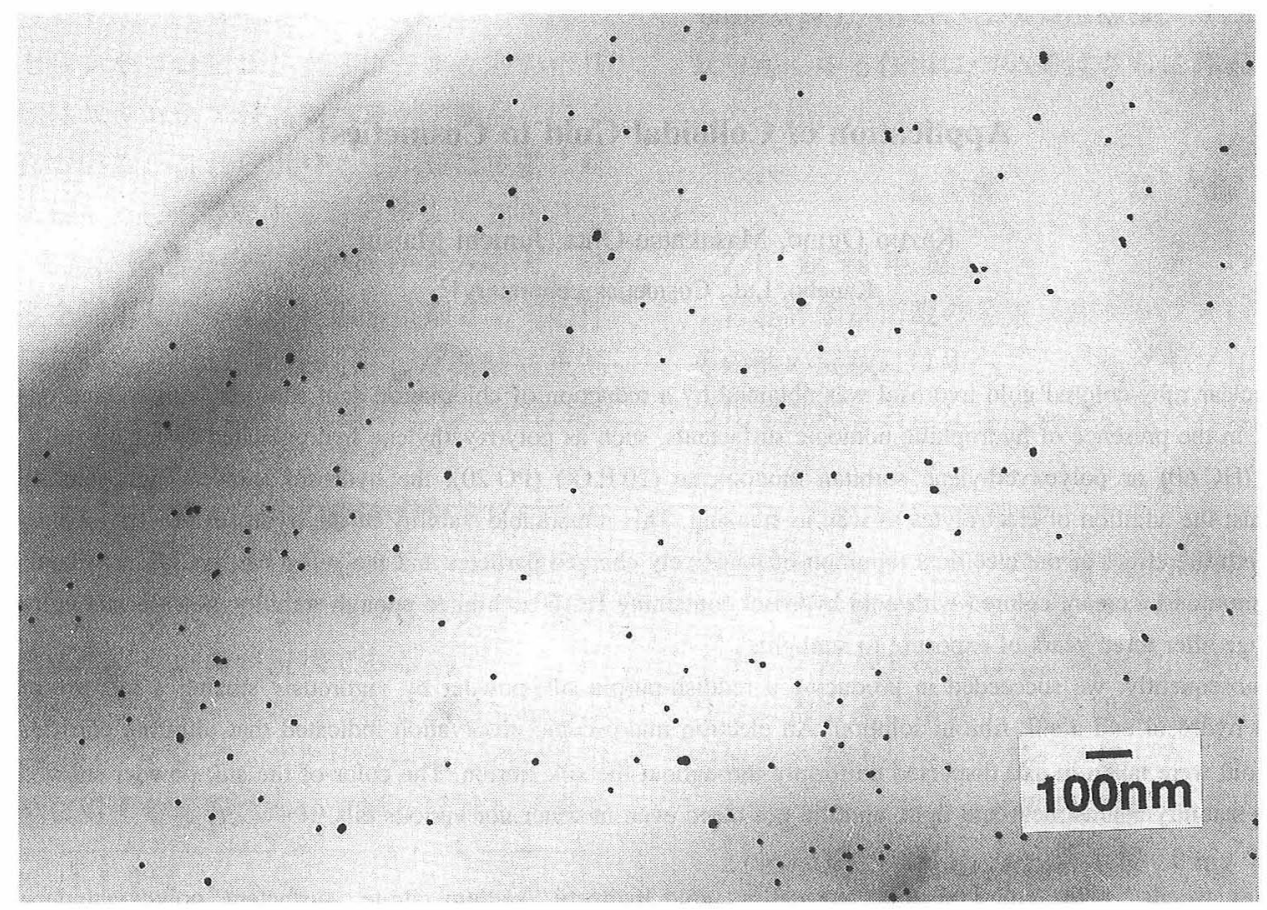

Fig. -5 Electron micrograph of a cross section of the silk powder containing gold particles 
モノオレイン酸ポリオキシエチレンソルビタ ン(20 E.O.)のような特定の親水性非イオン 性界面活性剂を添加すると電解質や凍結に対 する安定性が，格段に向上した。

2）この安定化は，負に帯電した金微粒子同士 の電気的反発と金微粒子表面に吸着した界面 活性剤が，ポリオキシエチレン鎖を水中に伸 ばしていることによる立体的防御の二つの効 果によって，金微粒子の凝集が，防がれてい ることによるものと考えられる。

3）クエン酸ナトリウムで還元しポリオキシエ チレン硬化ヒマシ油(60 E.O.)を添加して安 定化した金ヒドロゾルを配合して着色した口 一ションやクリームは，太陽光暴露下で 3 年 間にわたって色調が全く変化せず，極めて安 定性の高いものであった。

4）この金ヒドロゾルは, 皮膚一次刺激, 皮膚 累積刺激, 眼粘膜刺激, 感作性, 変異原性, ヒトパッチ試験の結果，すべて陰性であり皮 膚に対して安全なものであった。

5）この金ヒドロゾルと絹フィブロイン水溶液 とを混合, 強覮拌するとフィブロインが結晶
化して赤紫色のシルクパウダーが得られた。 これを TEM 観察すると, 金微粒子は, フィ ブロイン中に均一に分散していることが確認 された。

6）このシルクパウダーの色は, 熱や光に変色 せず, 水や油に滲み出ることがないなど安定 性の高いものであった。

\section{参 考文 献}

1) Y. Nakao and K. Kaeriyama, J. Colloid Interface Sci., 110, 82-87 (1986)

2 ) N. Ueda, M. Nishino and E. Suito, J. Colloid Interface Sci., 43, 264-276 (1973)

3 ) H. Hirai, J. Macromol. Sci. Chem., A 13(5), 633-649 (1979)

4) J. Turkevich, P.C. Stevenson and J. Hiller, Discuss. Faraday Soc., 11, 55-75 (1951)

$5)$ B. Jirgensons and M.E. Straumains, A Short Text Book of Colloid Chemistry 2nd Edition, Pergamon Press, New York (1962), p.329

6 ) J. Turkevich, Gold Bull., 18, 86-91 (1985)

7) Y. Nakao and K. Kaeriyama, J. Appl.Polym. Sci., 36, 269-277 (1988)

\title{
Application of Colloidal Gold to Cosmetics $\dagger^{1}$
}

\author{
Kazuo Ogino, Masakatsu Ohta, Junichi Matsui \\ Kanebo, Ltd., Cosmetics Laboratory $\dagger^{2}$
}

\begin{abstract}
A clear ruby-colored gold hydrosol was obtained by a reduction of chloroauric acid solution with sodium citrate. In the presence of hydrophilic nonionic surfactants, such as polyoxyethylene hydrogenated castor oil (60 E. O.) (HC 60) or polyoxyethylene sorbitan monooleate (20 E.O.) (PO 20), the hydrosol showed high stability against the addition of electrolytes as well as freezing. This remarkable stability of the hydrosol can be ascribed to both the effect of the electrical repultion of negatively charged particles and the steric barriers of surfactants. A lotion and a cream colored with gold hydrosol containing HC 60 exhibited enough stability to withstand color change after three years of exposure to sunlight.

Subsequently, we succeeded in producing a reddish-purple silk powder by vigorously stirring a mixture of gold hydrosol and a silk fibroin solution. An electron microscopic observation indicated that ultrafine particles of gold were taken in and dispersed uniformly throughout the silk fibroin. The color of the silk powder showed high stability against heat and light, and did not bleed even in water nor various oils.
\end{abstract}

Key words : gold, colloidal gold, cosmetics, gold hydrosol, sodium citrate, surfactant, polyoxyethylene hydrogenated castor oil, silk powder, fibroin, ultra fine particle, coloring matter, cosmetic pigment 